\title{
Flaubert's Hat Trick, Or The Pleasures of Banality
}

JS: I think it is Julian Barnes, in Flaubert's Parrot, who describes the French author as the "butcher of Romanticism and the inventor of Realism." I wonder if the latter accolade is fully justified by the well-known passage below that describes, in loving, hateful detail, the school-boy cap of Charles Bovary:

It was one of those head-gears of composite order, in which we can find traces of the bearskin, shako, billycock hat, sealskin cap, and cotton night-cap; one of those poor things, in fine, whose dumb ugliness has depths of expression, like an imbecile's face. Oval, stiffened with whalebone, it began with three round knobs; then came in succession lozenges of velvet and rabbit-skin separated by a red band; after that a sort of bag that ended in a cardboard polygon covered with complicated braiding, from which hung, at the end of a long thin cord, small twisted gold threads in the manner of a tassel. The cap was new; its peak shone. (Translated by Marx-Aveling)

I am imagining the oratorical Flaubert, bellowing out those three sentences, five hours into his twelve-hour writing day, until the hideous hat of young Bovary begins to become, through the alchemy of style, a triumph of le mot juste, in other words, at once a simulacrum and an anticipation of the grand performance-the miraculous hat trick-that transforms a bored, petit-bourgeois farm girl, a voluptuously sentimental Emma, into Madame Bovary, a work of art. That hat is doubtless an example of both realism and symbolism, but its expressiveness-editorially insisted upon in the passage itself-is part of a new language game, for which

How to cite this book chapter:

Begam, R. and Soderholm, J. 20I 5 . Flaubert's Hat Trick, Or The Pleasures of Banality. In: Begam, R. and Soderholm, J. Platonic Occasions: Dialogues on Literature, Art and Culture. Pp. 3-17. Stockholm: Stockholm University Press. DOI: http://dx.doi.org/Io.I6993/sup.baa.a. License: CC-BY-NC-ND. 
the words “Absolute Style" (Flaubert's own words in his letters to Louise Colet) are an abbreviation. That game has intrigued me for decades. And it makes one of my favorite novels also one of the funniest novels ever written. I think that in all the fuss made about Flaubert as a Realist, one forgets that he is also a humorist of the highest order, as boisterous as Rabelais, as witty as La Rochefoucauld, as darkly comical as Voltaire. What happens if we put on that imbecilic cap as a thinking cap, as Flaubert did for five years during the composition of Madame Bovary?

RB: Homer gives us epic ekphrasis with the shield of Achilles. Flaubert gives us bourgeois ekphrasis with the hat of Charles Bovary. And lest we miss the connection, the master of le mot juste drives home his classical allusion by calling the hat une casquette, variation on casque or "helmet." As you point out, the hat trick metamorphoses the base metal of everyday life into the precious gold of art. But it also-in wonderfully perverse and distressing ways-does the opposite: it suggests that Flaubert's precious metal may itself be fool's gold. And this is where the Homeric allusion again becomes important. For we must remember that it is Hephaestus who engages in the poiessis or "making" of Achilles' shield. While Homer's poetic model is an Olympian deity, Flaubert's is a provincial hat-maker; while Homer is inspired by Heaven ("Sing, Athena, of the wrath of Achilles"), Flaubert's muse is a shopkeeper ("Sing, O Milliner, of the stupidity of Charles").

You of course know the letter of I 6 January I 852 to Louise Colet in which Flaubert speaks of his desire to write a book "about nothing, dependent on nothing external, which would be held together by the internal strength of its style, just as the earth, suspended in the void, depends on nothing external for its support; a book which would have almost no subject." Charles's grotesque hat and the empty head it goes on is a symbol of this vacuity. In a sense, Flaubert's subject is his lack of a subject. In a sense, his art is about its own debasement into meaninglessness and insignificance.

John Updike once said that Andy Warhol's art has "the powerful effect of making nothing seem important." Of course, the "nothing" here includes Warhol's art. I would argue that this is 
precisely how Flaubert-living in the post-ideological aftermath of I 848-conceived of his own art. Charles Bovary's hollow headpiece is, in other words, the nineteenth-century equivalent of a can of Campbell's soup_-presumably Vichyssoise rather than tomato-and Flaubert is painfully aware of the implications this has for his aesthetic project. His hat trick consists in creating a world "suspended in the void." But he remains uncertain whether his lapidary expression will be sufficient to supply the emptiness of his occasion. Bereft of deities, will he remain a Homer? Or will he become the literary equivalent of a provincial hat-maker, artfully gluing together felt and feathers?

JS: Given what "happens" in Bouvard et Pécuchet-the two clerks hovering over the void of their utter banality and uselessness-I think perhaps the hat trick becomes something almost Beckettian in its dire iterations. Is literary nihilism the result of the art of nothingness? Does Flaubert pass the hat to Beckett? I don't necessarily want to navigate away from our beloved bovarysme, but I wonder if you think this connection has any "substance" to it?

RB: Kant's genius was to have discovered the uselessness of art. Flaubert's was to have discovered the usefulness of banality. Taken together, they provide a text-book definition of Zweckmässigkeit ohne Zweck-of a purposeless purposivenessand Beckett is their grateful heir.

But there is another antecedent to the art of uselessness and banality: William Wordsworth. You've spent a good deal of time meditating on Wordsworth's relation to Byron. What about his relation to Flaubert? The leech-gatherer is banal and his vocation largely useless, yet Flaubert's satire becomes Wordsworth's heroism. And what of the latter's Idiot Boy? How different from the imbecile Charles Bovary. And yet how similar.

JS: At first Byron spanks the hell out of the "Idiot Boy" in English Bards and Scotch Reviewers, but much later he writes "Unjust" in the margins of his own satire on Wordsworth. I think the so-called "democratization of subject matter" that is often 
attributed to Wordsworth goes back at least to Burns and his mouse and louse and perhaps also sends a taproot to Defoe's assiduous account of how Crusoe makes bread. When Wordsworth actually measures mud puddles in Lyrical Ballads, he anticipates later experiments in artistic banality, and no doubt the Idiot Boy somehow gives birth ("the child is the father of the man") to Charles Bovary. In both cases, a kind of expressive imbecility capers first as "Romanticism" and then as "Realism," although the actual experiments are, I think, far more interesting and entertaining than the "isms" that would purport to explain them.

But I am still left wondering what Byron meant by that belated judgment: "Unjust." Did he fail to imagine Wordsworth (in his early phase, at least) as a potentially comic poet? Is that failure somehow connected to an inability to see just how hilarious Flaubert is when he depicts Homais as the Bourgeois Satan? And yet, next to the shield of Achilles and Homer's epic grandeur, isn't there something truly miserable and depleted about making leechgatherers into the stuff of poetry?

RB: Certainly Flaubert is participating in the democratization of subject matter, as Jacques Rancière has argued. But I wonder if his literary project isn't finally more radical than that. He is, after all, not simply valorizing the everyday, but insistently aestheticizing it. For him the kitschiest of objects—whether Charles's hat or Emma's heart—are not merely suitable subjects for the artist but the only subjects available to him. In a world where Bouvard and Pécuchet can imagine themselves as Diderot and d'Alembert, the artist's instrument is no longer a Homeric lute but a cracked kettle; and his melodies no longer make the stars-or the gods-weep, but set bears dancing. Translated to post-I 848 France, Achilles' shield is a writing desk built for two idiots (one is not enough). Translated to I960's America, Achilles' shield is a can of Campbell's soup reproduced a hundred times (it's simulacra all the way down).

When Flaubert famously proclaimed, with a nod to Louis XIV, "Madame Bovary c'est moi," he was being lethally comic and deadly earnest. A writer cannot escape his own time or place. It is not simply a rabbit that Flaubert has pulled out of Charles's hat. It is himself. 
JS: It is the trickiest hat in town. For two decades students have asked me what "Madame Bovary c'est moi" means. Two things come to mind. Henry James referred to Flaubert's "puerile dread of the grocer" and Roland Barthes wrote that the "one thing we cannot avoid is being middle class." I think Flaubert's cracked kettle makes beautiful music, even in translation-the very thought of which must have made Flaubert's gorge rise-but that music, as you suggest, must necessarily be less grand than Homer's chanting, haunting, murderous dactylic hexameter. And yet why are we so mesmerized by Achilles slaying Trojan boys in a river? What is Homer's hat trick? To make murder beautiful? I think of Emma's death bed and the moment when, a few hours after she "ceased to exist," someone tilts up her head slightly and a stream of black blood pours like old motor oil from her mouth. Gorgeous sentences, disgusting details. It is not merely the only modernist language game in town, but really one of the oldest and most venerable games, or tricks. Life has always been essentially shabby. And art has always been essentially an attempt to turn it inside out, magically, so that the content vanishes and the purposeless purposiveness porpoises, breaking the surface, disporting as form, a shimmering arc.

RB: In I86I, five years after the appearance of Madame Bovary, Charles Baudelaire published Les Fleurs du Mal. The slender volume included a meaty little valentine called "Une Charogne." The poem begins conventionally enough with a young man asking his lady if she recalls a beautiful summer day they shared. But then it takes an unpredictable turn. In the remembered scene, the lovers come upon the grotesque remains of a rotting carcass, its legs thrust in the air "like a woman in heat." Here are four of the central stanzas, freely translated:

The flies buzzed on the putrid belly, From which issued black battalions of larvae

Flowing like a thick liquid

Along a pile of living rags.

The whole fell and rose like a wave,

Or erupted into a sparkling foam; 
One would have thought that the body, Swollen by a vague breath, was living, multiplying.

This world emitted a strange music,

Like running water and wind,

Like the grain that a winnower, with a rhythmic motion, Shakes and turns in his basket.

The forms erased themselves, became mere dream, A rough sketch tentatively shaping itself, On a forgotten canvas that the artist Completes only in his memory.

If Homer kills boys in a river, Baudelaire murders love on a garden path. Of course, the carcass is itself a symbol. At one level, it provides a mordant commentary on the Lamartinian tradition of romance, a memento mori for all who would append "evermore" to the word "love." On another level, the carcass seems to reanimate itself, to take on a lubricious life of its own, insisting in darkly Sadean ways on erōs's fascination with thanatos. Of course, what is important for our purposes is the relation between Flaubert's hat trick and what we might call Baudelaire's pet trick. The poet, like the novelist, is radically rewiring our aesthetic circuits, discovering beauty in the unlikeliest of places, demonstrating how art can transfigure rotting flesh into music, rhythm and dream. Just as Flaubert anticipates Warhol's soup cans, Baudelaire anticipates Robert Mapplethorpe's anal whip and Carolee Schneemann's vaginal scroll.

One might argue that these hat-and-pet tricks are profoundly Kantian. How better to demonstrate the artist's legerdemain than by showing how completely form has trumped content? Yet one could just as plausibly argue that these tricks are profoundly anti-Kantian. By corporealizing art, by rubbing our nose in its fleshy, shitty, mucous-laden materiality, artists like Baudelaire, Mapplethorpe and Schneemann destroy aesthetic disinterestedness. Life and art are no longer cordoned off from each other. The ontological divide that separated them is breached, and the everyday, the odious and the obnoxious tumble into the privileged space of Kantian aestheticism. 
To what degree, I wonder, is the phenomenon I have been describing the result of an imperative to innovate? Does the endless drive to "rouse the faculties" (Blake), to "make it new" (Pound), to "negate tradition itself" (Adorno) lead to an art that is so perverse, trivialized and marginalized that it finally ceases to be art. In making art everything, did Flaubert and Baudelaire ultimately make it nothing?

JS: Indeed, and how far can art be (about) nothing and still be recognizable as art? The answer seems to be: one hell of a lot! You earlier avoided my reference to Beckett's contribution to the fecund imbecility we have been discussing. After all, our beloved tramps wore hats. Are Bouvard and Pécuchet (and Rosencrantz and Guildenstern before them) the forebears of Vladimir and Estragon? In negating both dramatic and novelistic traditions, did Beckett give us "sparkling foam" in his "spray of phenomena"? If you want to give this another pass for now, then why not hop into Tracey Emin's bed? Her My Bed (an installation of her actual bed strewn with underwear and condoms, the sheets stained by her unprecious bodily fluids) makes the cap of Charles Bovary look almost heroic by comparison. I think it's a short stroll from the loo (Duchamp's Fountain) to Emin's bed. Has “art” ever been so banal, so personal, so emptily symbolic, and so formally bankrupt? I have to imagine Turner doing about $4500 \mathrm{rpm}$ in his grave, given that Emin was short-listed for the I 999 prize bearing his name. Now a British luminary of some repute, Emin has succeeded in making "art" out of the detritus of her cannily-disheveled, overexposed and depressive life.

If Emin's bed does not entice-and heaven knows why it should-then I suggest we walk around in Van Gogh's "Peasant Shoes" and recall Heidegger's phenomenological treatment of them. Apparently Van Gogh picked up the shoes in a flea market (the origin of the modern work of art?) but they were not sufficiently worn and beaten up for him so he walked around in them in the rain until they looked a bit more "peasanty," and then he painted their Heideggerean "truth" in all its miserable detail, thus taking us as far as possible from Plato's "Shoeness" in the 
direction of the "thingly" and "worldly" character of things and worlds.

Hephaestus did not cobble those shoes. Sing, O Cobbler, of the Truth of Peasants. We live in a time when the foul rags of the human heart have an odd vitality, when even mud puddles can rise into a wave. But I still think the exquisite corpse of art is strangely connected to Homer's performance, where fish rise to nibble on the blood streaming from dead Trojans as they float to immortality. And what do we make of how wrathful Achilles ends up in Hades, vaguely repenting his short, happy and murderous

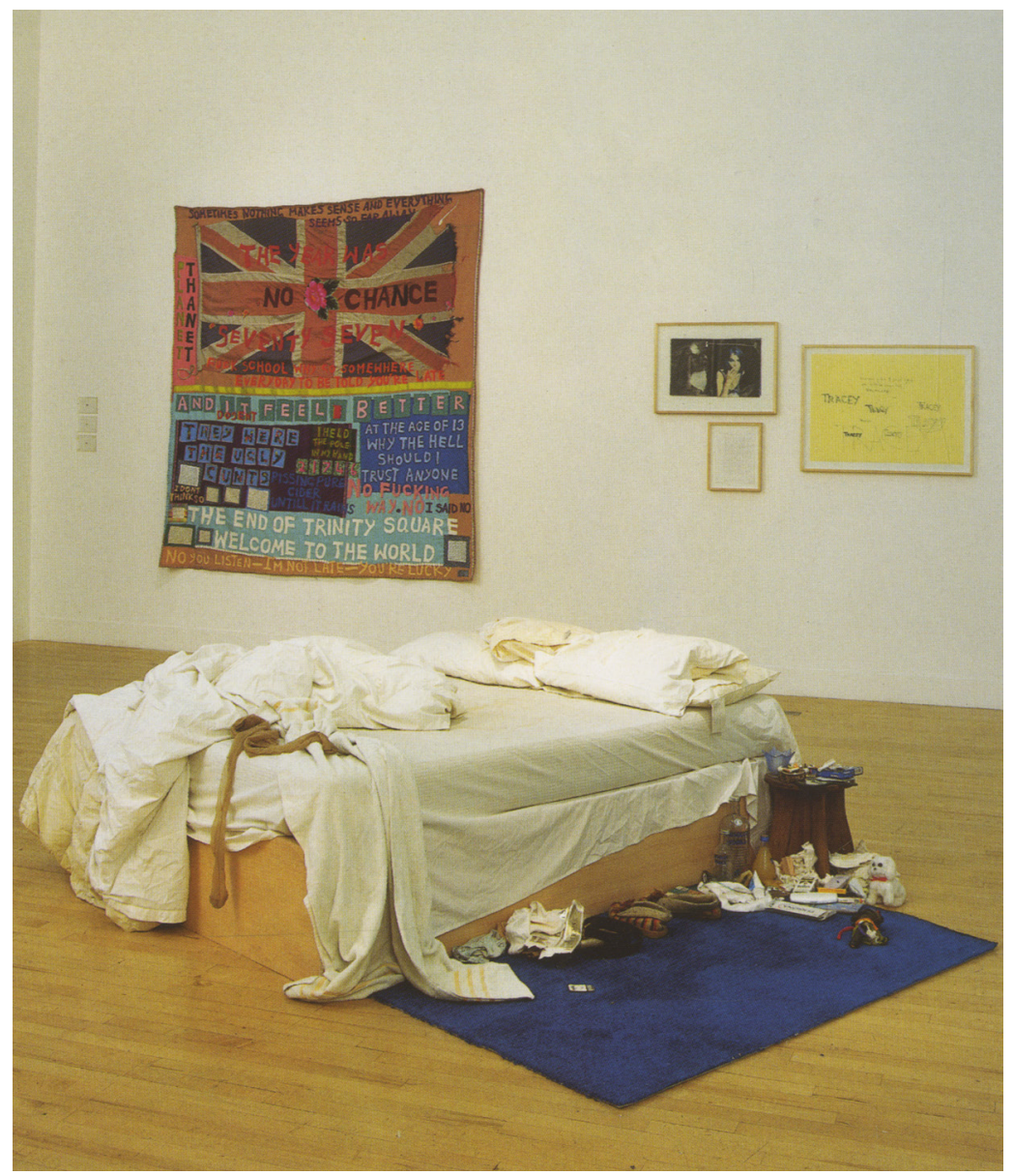

Figure 1: Tracey Emin, My Bed. (๔ 2014 Tracey Emin. All rights reserved.) 
life, wishing he could return to life as Charles Bovary wearing Van Gogh's peasant shoes?

RB: Much is made of hats throughout Beckett's corpus. Usually they function as comic props for staging mind/body dualism as a series of music-hall gags. Lucky puts on his bowler to think, and Vladimir takes off his because it "irks" him, while Molloy secures a straw boater to his body with an elastic band. For Flaubert the hat is the symbol of an absent or evacuated mentality. For Beckett it is the symbol of a fugitive or contingent cognition. Both writers are post-Enlightenment figures, for whom the mind is in retreat. And yes, Vladimir and Estragon have many forebears, comedians and ironists all, from Laurel and Hardy, Bouvard and Pécuchet, Rosencrantz and Guildenstern to Quixote and Panza, not to mention Socrates and the Youth of Athens. Wherever mind dialogically examines itself, wherever it puts questions, invents answers, engages in repartee-there one finds Didi and Gogo.

Are Flaubert's and Beckett's banality the same as Tracey

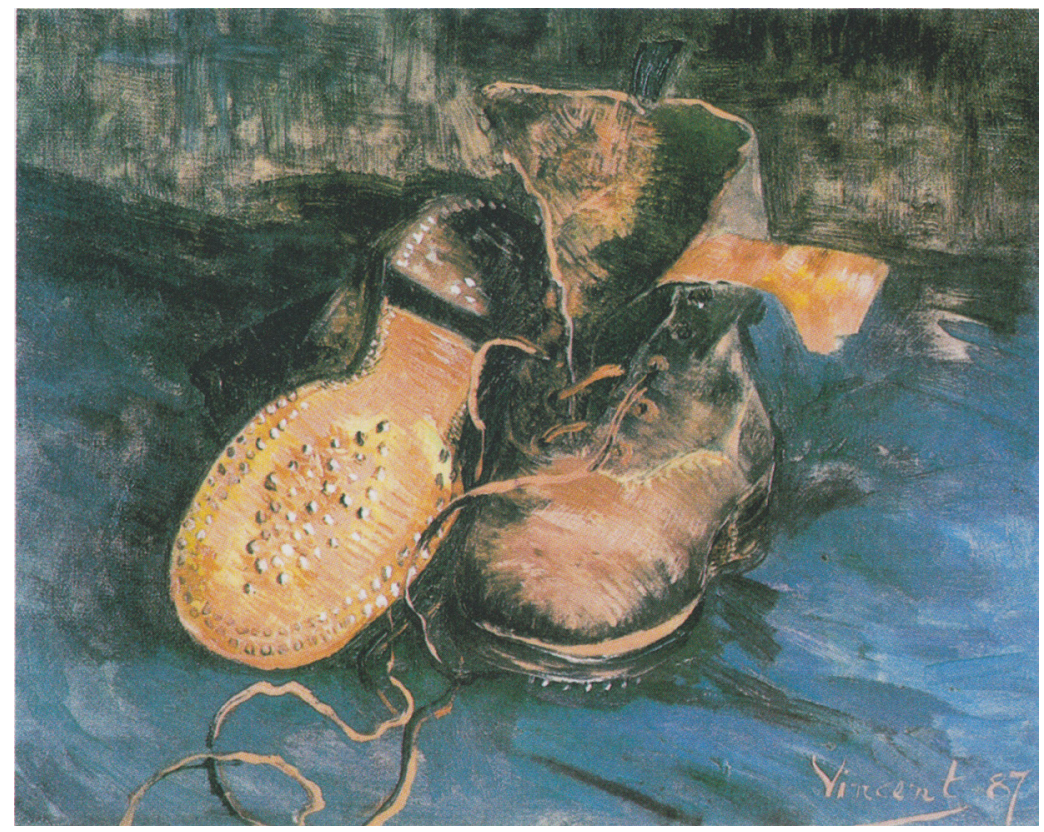

Figure 2: Vincent Van Gogh, A Pair of Boots. (The Baltimore Museum of Art). 
Emin's? Ontologically speaking, yes. Critically speaking, no. Emin has produced a work of art-that is, a work whose function is aesthetic not practical. To be sure, one could sleep in her bed, but clearly a good-night's rest does not begin to describe its "purposive" structure. In the Kantian sense, its purposiveness is purposeless (it has no "real-world" function), which means that it belongs in a museum rather than in a bedroom; or, to speak more precisely, which means that it is a candidate for exhibition in a museum. A curator with any critical standards-which excludes the Saatchi Gallery and the Turner Prize committeewould reject Emin's work for the trash it is. In this regard, she has nothing in common with Flaubert and Beckett: they have produced great art, while she has merely engaged in narcissistic exhibitionism.

I think you are right to suggest that a continuum runs from Homer to Flaubert, Baudelaire, Van Gogh and Beckett. Artists have always worked with form and content. They must have something to say, and they must say it in a distinctive and compelling way. But much of the art we call modern is born out of a crisis of subject matter, a sense that we live in an age so frivolous, vulgar and insubstantial that the relation of form to content has become vexingly problematic. Flaubert and Baudelaire initiated a tradition in which the detritus of modern life emerges as a major preoccupation, the thematic axis of an art that is obliged to discover a form appropriate to its content. Warhol pushes this tradition to the brink of kitsch and then pulls back at the last minute, bracketing it with a kind of peek-aboo irony. By contrast, Emin's art doesn't even know what kitsch is. Purposiveness has gone all slack and rumpled, and poiesis has (like her bed) become so "unmade" that there's simply no "there" there.

The ekphrasis of Achilles' shield is a fit emblem for great art, which always opens up an alternative universe, one that is rich, complex, capacious. Emin's art is about as complex and capacious as a bag of dirty laundry. There is an inert literalness to it. She has the sensibility not of an artist but of a stock clerk.

JS: And that is precisely what separates Emin from Emma. For all her tedious and finally lethal sentimentality, Emma has, Flaubert tells us, "an artistic sensibility" that allows the author, however 
archly, to identify with her ("Madame Bovary c'est moi”). Emin might also say of her work-using a contemporary and blandly narcissistic idiom- "My bed, Myself" but this close alliance with one's work is a false intimacy and even less exciting and aesthetically compelling than getting into bed with yourself. The cap of Charles Bovary, to return to Flaubert's generative conceit, or fecundating ekphrasis, is not only the opposite of literalism-as we have suggested-but even beyond symbolism. It is the music of the future, all the more impressive because of its impoverished resources, like getting a Shostakovich symphony out of the xylophone of a rotting rib cage, or torturing a parrot until it sings like Mimi in La Bobème: modern art as a collection of cracked kettles implausibly wringing tears from the stars. The art of detritus and the detritus of art. I suppose we do need Homer's epic grandeur to "shield" us from modernity, postmodernity and the fact that art has become a hat trick, or a trick hat, that nearly makes us forget how much art has now "installed" itself as dirty laundry. Before we move back to another passage in Madame Bovary, I am naturally wondering how Eliot's The Waste Land fits into the picture we have been describing. All those broken images. All that impotence.

RB: Emin is, as you say, blandly narcissistic, but the problem is not narcissism per se as the cases of Proust and Joyce demonstrate, both of whom were colossally self-obsessed. If an artist takes himself as his subject, he needs to discover in that subject something more than his own identity-a broader significance that moves his art beyond literal self-presentation. The epiphany enabled Proust and Joyce to accomplish this. In their hands an ordinary object or event is transfigured, pushed into the realm of the transcendent. A cake dipped in tea becomes a communion wafer that shatters space and resurrects time; a girl on the beach becomes an aesthetic summons that forges the uncreated conscience of the race. Emin's bed, on the other hand, is a tired tautology. It functions according to the same logic as a blogger who documents what she ate for breakfast and all her visits to the bathroom. We cannot say the same of Charles's hat. Like Achilles' shield, it is a metaphor and a metonym for an entire culture and the art it produced. Similarly the fragmentation and impotence of The Waste Land acquire 
integrity and power, with Eliot re-imagining his personal suffering (he called the poem so much "rhythmic grumbling") as the experience of an epoch and its relation to tradition.

Mimi is an artist because she is able to sing about something other than herself. Emin sounds the same note over and over: Me, Me.

JS: We discuss narcissism and the "Me Me Tradition" in another dialogue in relation to Whitman's "Song of Myself," which stands to America rather in the same position as Virgil's Aeneid stands to Italy: as both national myth and founding epic. Whitman's experiment in combining a national epic with what Keats called "the egotistical sublime" produces some great poetry and some nauseating conceits, for example the line, "The scent of these arm-pits' aroma finer than prayer" from the opening of "Song of Myself." But those arm-pits are meant to be America's lovely stench, not merely Whitman's, an expansiveness that puts him leagues beyond Emin's fetid bed. That aroma, as distinctive in its own way as tea-soaked madeleine cakes for little Marcel, evokes an entire world, or perhaps a body-politic.

I'd like to return to Madame Bovary for a moment and another "cap" of sorts. This one is the cake constructed for the wedding of Emma and Charles:

A confectioner of Yvetot had been entrusted with the tarts and sweets. As he had only just set up on the place, he had taken a lot of trouble, and at dessert he himself brought in a set dish that evoked loud cries of wonderment. To begin with, at its base there was a square of blue cardboard, representing a temple with porticoes, colonnades, and stucco statuettes all round, and in the niches constellations of gilt paper stars; then on the second stage was a dungeon of Savoy cake, surrounded by many fortifications in candied angelica, almonds, raisins, and quarters of oranges; and finally, on the upper platform a green field with rocks set in lakes of jam, nutshell boats, and a small Cupid balancing himself in a chocolate swing whose two uprights ended in real roses for balls at the top.

I like to think of that outrageous wedding cake as an echo of the description with which we began this dialogue. Like Charles's hideous hat, the wedding cake is an assemblage of dis- 
parate parts— "heterogeneous materials by violence (egg)yoked together"-that suggests a talent for ransacking various cultures and mythologies in order to make them purely decorative. In other words, out of the kitchen, kitsch: a sweet confection where Greek porticoes are made of cardboard. It is just the kind of wedding cake-elaborate, sentimental and voluptuous-that Emma would have loved to create (did she give the confectioner instructions?). The wedding cake as a well-wrought, if not overwrought, urn: an object of wonderment and a joy forever.

Flaubert presents us with a series of failed or fake artists in Madame Bovary, people struggling to be "artistic" but ending up as hacks, charlatans and mere confectioners of beauty. Emma herself is such a failed artist, struggling to make her house into a work of art (a French Martha Stewart) and, failing in that, struggling to make her life into a work of romantic fiction, the kind of fiction she read in the convent as a girl. The most hilarious and obscene example of the pretentious but failed artist is Binet, Yonville's tax collector, who bends over his would-be lapidary lathe to turn out hundreds of napkin rings (pure purposelessness). We are on our way to Warhol's soup cans, except without the saving irony-and without Flaubert's contempt for such mass productions, the verbal equivalent of which he catalogues so assiduously, comically and pungently in his Dictionnaire des idées reçues, which he also called an "encyclopedia of human imbecility," the same imbecility that one sees in the cap of Charles, whose "dumb ugliness has depths of expression." Obsessed with le mot juste, Flaubert pours scorn on all those who haven't his genius for that alchemy by which "patterns of provincial life" (the novel's subtitle) become ornate, precise and beautiful sentences. Flaubert is also a confectioner of words, but the wedding cake he builds is a minor work of art, not a laughable piece of kitsch. He performs this hat trick over and over in Madame Bovary so that we can mark the distance between the artist and the hack, a distinction lost in a world where filthy beds and hoaxing artists take away prizes, like Homais receiving, in the last sentence of the novel, "the cross of the Legion of Honor."

RB: If the hat is a synecdoche for Charles's head, the cake is 
a synecdoche for Emma's bed, her imagined romantic and erotic life, which combines temple, dungeon and fortification with sugary illusion. And as you observe, the cake is both an art object in its own right (a Tower of Babel built of mots justes) and a symbol of what art becomes in bourgeois culture: a form of domestic ornamentation. Of course, the novel itself is the form par excellence of bourgeois and domestic culture, a fact that Flaubert both understands and exploits.

In Theory of the Novel, Georg Lukács remarks, "Art always says 'And yet!' to life. The creation of forms is the most profound confirmation of the existence of a dissonance." Art needs the idiotic and jumbled mess that is the object-universe of bourgeois culture, all those disparate and conflicting styles that make Charles's hat and Emma's cake into a potpourri of kitschy excess. Homais' receiving the Legion of Honor at the end of Madame Bovary is typically read as Flaubert's mordant comment on the inevitable triumph of mediocrity and mendacity in nineteenthcentury France. But I wonder if Flaubert's relation to Homais isn't more complicated than that. After all, Flaubert's Absolute Style has transformed even a despicable pharmacist into a wellwrought object, art's “And yet!"-its “O mais!”-to life. I think something of the same transformation, though admittedly in a far more sympathetic vein, takes place with both Charles and Emma. And it has everything to do with such grotesque creations as the hat and the cake.

Somewhere Walter Benjamin speaks of the trashy, massproduced objects that furnished the comfortable home of his Berlin childhood. While he later recognized that many of these objects were pure kitsch, he nevertheless retained a profound affection for them because of the memories they carried. One of the most startling aspects of Flaubert's genius is his ability to ironizealmost to the point of obliteration-all the shoddy bric-a-brac of bourgeois culture, while at the same time reproducing it with what can only be described as a lover's attention to detail. He hangs on the hat and the cake as Romeo hangs on Juliet's lips. So too with Flaubert's characters. If Emma is ultimately redeemed by her passion-her poignant and rather desperate belief that there is more to life than the banality of provincial existence-Charles 
is ultimately redeemed by loving Emma for her passion-which is to say, by loving Emma for hating everything he represents. One can imagine nothing further from the narcissism of Tracey Emin.

Here, in the Steegmuller translation, is the final scene of the novel:

The next day Charles sat down on the bench in the arbor. Rays of light came through the trellis, grape leaves traced their shadow on the gravel, the jasmine was fragrant under the blue sky, beetles buzzed about the flowering lilies. A vaporous flood of lovememories swelled in his sorrowing heart, and he was overcome with emotion, like an adolescent.

At seven o'clock little Berthe, who hadn't seen him all afternoon, came to call him to dinner.

She found him with his head leaning back against the wall, his eyes closed, his mouth open; and there was a long lock of black hair in his hands.

"Papa! Come along!" she said.

She thought he was playing and gave him a little push. He fell to the ground. He was dead.

What is the most profound love? The one in which the lover becomes the beloved. Cathy is Heathcliff, and in his final hour Charles is Emma. To his credit, Flaubert never succumbs to sentimentalism. Charles's flood of love is "vaporous," and he is overcome with emotion like "an adolescent." Can anything be more clichéd than dying for love, as Charles does? And yet (O mais!) can anything be less like Charles than dying for love? How far has he traveled beyond himself-beyond his own clichés-to become someone else's cliché? In a sense, Flaubert reverses the terms proposed by Benjamin. An object that initially struck us as pure kitsch, has begun to acquire value, substance, meaning. Flaubert has himself redeemed his Idiot Boy. Should we now, à la Byron, write in our own margins "Unjust" ?

JS: Unjust and juste simultaneously. Great art puts us right there. 